\title{
EVALUATING THE EFFECT OF IRRIGATION NUMBER ON GROWTH, YIELD, STORABILITY AND WATER PRODUCTIVITY OF SOME ONION VARIETIES
}

\author{
"Morsy, M.G. and K.M. Abd El- Latif **
}

*Field Crops Res. Inst., Onion Depart. ** Soils, Water and

Envir. Res. Inst. (SWERI), Water Requirements and Field

Irrigation Depart. Agricultural Research Center, ARC, Giza, Egypt.

\section{ABSTRACT}

Field experiments were conducted during 2008/2009, 2009/2010 and 2010/2011 seasons at Sids Agric. Res. Station, Bani-Swief Governorate, Egypt. These trials aimed at investigate the effect of irrigation number, i.e. $\mathrm{I}_{1}$ : transplanting irrigation (TPI), $\mathrm{I}_{1}$ : TPI + Live irrigation (LI), $\mathrm{I}_{3}: \mathrm{TPI}+\mathrm{LI}+2^{\text {nd }}$ irrigations and $\mathrm{I}_{4}$ : TPI $+\mathrm{LT}+2^{\text {nd }}+3^{\text {rd }}$ $+4^{\text {th }}$ irrigations on vegetative growth, bulb yield, storability and water productivity of three onion varieties namely $\mathrm{V}_{1}$ : Giza 6 Mohassan, $\mathrm{V}_{2}$ : Giza 20 and $V_{3}$ : Giza Red. A split-plot design with four replicates was used. The most important results could be summarized as follows:-

1- Plant height, leaves number/plant and bulb diameter were significantly increased with increasing irrigation to $\mathrm{I}_{4}$ treatments in the three seasons. Giza Red variety significantly surpassed Giza 6 Mohassan and Giza 20 in these growth characters in all seasons. Growth attributes were significantly affected by the interaction between irrigation and varieties except for plant height in the $1^{\text {st }}$ and $3^{\text {rd }}$ seasons and bulb diameter in the $2^{\text {nd }}$ season.

2- Irrigation treatments and varieties significantly affected bulb weight, dry matter presentage, days to maturity, marketable yield, culb and total yield in the three season. The higher values of marketable yield, i.e. $12.60,13.06$ and $13.45 \mathrm{t} /$ fed., as well as total yield, i.e. 15.74, 15.37 and 16.10 t/fed. In 2008/2009, 2009/2010 and 2010/2011 seasons, respectively were detected from $\mathrm{I}_{4}$ irrigation treatment and Giza Red variety. However, the dry matter (\%) decreased with increasing irrigation number in all seasons.

3- Water consumptive use values over irrigation treatments and varieties were $766.88,798.7$ and $792.1 \mathrm{~m}^{3} / \mathrm{fed}$. in $2008 / 2009$, $2009 / 2010$ and 2010/2011 seasons, respectively, including the transplanting irrigation. Irrigation Giza 20 variety at 5 irrigation $\left(\mathrm{I}_{4}\right)$ gave the highest consumptive use values, i.e. 1310.0, 1331.3 and $1316.3 \mathrm{~m}^{3} / \mathrm{fed}$ in the three successive seasons.

4- Increasing irrigation number applied resulted in lower water productivity for all varieties. Giza red variety irrigated one irrigation $\left(\mathrm{I}_{1}\right)$ was the more efficient variety in water utilization than Giza 6 Mohassan and Giza 20 varieties. These results were found to be true for water productivity. The highest water use efficiency, i.e. $16.88,25.20$ and $16.12 \mathrm{~kg} / \mathrm{m}^{3}$ water consumed in irrigated according to irrigation treatment $\left(\mathrm{I}_{4}\right)$, exhibited highest water consumptive use values as compared in 2008/2009,

Fayoum J. Agric. Res. \& Dev., Vol. 26, No.2, July, 2012 
2009/2010 and 2010/2011 seasons, respectively were observed from irrigating Giza red variety one irrigation only.

5- In the three seasons, lower values of bulb weight losses (\%) were obtained under the irrigation treatments, $\mathrm{I}_{3}$ after two and four months storage periods, whereas after six months, $\mathrm{I}_{4}$ irrigation treatment exhibited the lowest value. Also, lower values of bulb weight losses $(\%)$ were recorded by Giza 6 mohassan as compared with Giza 20 or Giza Red varieties.

Key words: Onion yield, irrigation level, water productivity, onion varieties, and storability

\section{INTRODUCTION}

Onion (Allium cepa L.) is one of the most important and widely used vegetable crops in the world. In Egypt, total harvested area was 61535 ha producing 2208080 metric tons (FAOSTAT, 2010). The unit of both water and area productivity still low and it is needed to be increased according to the increased people demands throughout improved agricultural practices i.e. sowing date, high- yielding varieties, proper both fertilization and irrigation management....etc. Optimum irrigation management is the most important factor affecting onion productivity and quality under the Egyptian conditions. Moisture stress is generally detrimental to plant growth and reducing both yield and quality of the crop. Nandi et al. (2002) and Abd El-Gawwed (2008) reported that growth and yield of onion were significantly affected by irrigation, but not post harvest life. In connection, Pelter et al.(2004) found that onion total yield was reduced by soil-water stress imposed at any growth stage but the greatest effect was at the 5-leaf, 7-leaf, and 3- and 7-leaf stages. El-Akram (2012) in Egypt, stated that onion bulb yield and water use were higher with frequently irrigation i.e. irrigating as $40 \%$ of available soil moisture was depleted, in comparison with irrigation at 60 and $80 \%$ ones. Indubitable, irrigation management affecting onion yield - water relations. Abu-Awwad (1999) reported that water use efficiency for onion, in the covered soil surface treatment, was maximum for the highest water level (197 mm irrigation). In this sense, Kadayifci et al. (2005) found that high water use and water use efficiencies were observed with increasing levels of irrigation, or no irrigation in the vegetative period. Irrigation is an important factor influencing onion storability, Rabbani et al. (1986) reported that storage losses in onion could be as high as $66 \%$, and many factors, such as cultivars, bulb maturity, moisture content of the bulb, temperature, relative humidity, etc. are associated with spoilage of onion during storage. In addition, a substantial increase of decomposition in onion during storage with increasing irrigation was reported by Shock $\boldsymbol{e t}$ al. (1998). Soujala $\boldsymbol{e t}$ al. (1998) reported that irrigation had only a minor effect on the storage performance and shelf life of onion.

The aim of this study is to investigate the effect of four irrigation treatments and three onion varieties on onion yield, yield components, storability as well as water productivity.

\section{MATERIALS AND METHODS}

The present research trials were conducted in 2008/2009, 2009/2010 and 2010/2011 growing seasons at the experiment of Farm of Sids Agricultural Research Station, Bani Swief Governorate (Middle Egypt, Lat. 29.40 N, Long.

Fayoum J. Agric. Res. \& Dev., Vol. 26, No.2, July, 2012 
EVALUATING THE EFFECT OF IRRIGATION NUMBER ON.....

$31.60 \mathrm{E}$ and $30.40 \mathrm{~m}$ above the mean sea level). The soil -moisture constants and physiochemical properties of the soil at experimental site according to Page et al. (1982) and Klute (1986) are listed in Tables (1) and (2), respectively. The trial aimed to investigate the performance of three onion varieties under four irrigation treatments. Onion crop growth, bulb yield and storability as well as crop water consumptive use and water productivity were considered.

The experiment was laid out in a split-plot experimental design with four replicates. Irrigation treatments were allocated to the main plots, while the assessed onion varieties occupied the sub-plots as follows:

1- Main plots (Irrigation, I):

$1_{1}=$ Transplanting Irrigation $(\mathrm{TPI})$

$1_{2}=(\mathrm{TPI})+$ Life Irrigation $(\mathrm{LI})$

$1_{3}=(\mathrm{TPI})+(\mathrm{LI})+2^{\text {nd }}$ Irrigation

$1_{4}=(\mathrm{TPI})+(\mathrm{LI})+2^{\text {nd }}$ irrigation $+3^{\text {rd }}$ irrigation $+4^{\text {th }}$ irrigation

2- Sub plots (Onion varieties, $\mathrm{V}$ ):

$\mathrm{V}_{1}=$ Giza 6 Mohassan $\quad \mathrm{V}_{2}=$ Giza $20 \quad \mathrm{~V}_{3}=$ Giza Red

The nursery was sown in the first week of September in the three seasons. Seedlings were transplanted after 55 to 60 days after seed sowing. The plot size was $3 \mathrm{~m}$ width $\times 3.5 \mathrm{~m}$ length (i.e. $1 / 400 \mathrm{fed}$ ). The seedlings were transplanted at spacing of $10 \mathrm{~cm}$ between plants and $20 \mathrm{~cm}$. between rows. Fertilization was applied according to the recommendation of the Ministry of Agriculture in Egypt as follows: $300 \mathrm{~kg} \mathrm{P}_{2} \mathrm{O}_{5} /$ fed during land preparation, 120 $\mathrm{kg} \mathrm{N} /$ fed. in two doses, and $100 \mathrm{~kg} \mathrm{~K}_{2} \mathrm{O} / \mathrm{fed}$. All the recommended cultural practices for onion production were applied and adapted to surface irrigation conditions. The applied irrigation water was measured using a water meter attached to the irrigation pump. The onion plants were grown to maturity and were considered mature when $50 \%$ of leaves fell down.. At 105 days post planting, a representative sample of ten plants from each plot was randomly taken to measure plant height, no. of leaves per plant, bulb diameter, bulb weight, dry matter percentage and days to maturity. At harvest time, when $50 \%$ of leaves fell down, the remaining plants in each plot were harvested and cured in the field for 10 days, then the shoots and roots were removed. The marketable culls and total bulb yields from each sub-plot were recorded and expressed in $\mathrm{t} / \mathrm{fed}$. In addition, for storability determination, about 150 bulbs were stored under room temperature condition and weight losses (\%) after 2, 4 and 6 months were recorded.

Fayoum J. Agric. Res. \& Dev., Vol. 26, No.2, July, 2012 
Table (1). Some soil water constants for the soil at experimental site.

\begin{tabular}{|c|c|c|c|c|c|}
\hline Season & Depth (cm) & $\begin{array}{c}\text { Field capacity } \\
(\%, w / w)^{*}\end{array}$ & $\begin{array}{c}\text { Wilting point } \\
(\%, \mathrm{w} / \mathrm{w})^{*}\end{array}$ & $\begin{array}{c}\text { Available water } \\
(\%, w / w)^{*}\end{array}$ & $\begin{array}{l}\text { Bulk density } \\
\left(\mathrm{gcm}^{-3}\right)^{*}\end{array}$ \\
\hline \multirow{4}{*}{$2008 / 2009$} & $00-15$ & 444.01 & 20.96 & 23.05 & 1.24 \\
\hline & $15-30$ & 40.90 & 19.48 & 21.42 & 1.34 \\
\hline & $30-45$ & 36.82 & 17.53 & 19.29 & 1.38 \\
\hline & $45-60$ & 36.37 & 17.32 & 19.05 & 1.38 \\
\hline \multicolumn{2}{|c|}{ Mean } & 39.52 & 18.82 & 20.70 & 1.39 \\
\hline \multirow{4}{*}{$2009 / 2010$} & $0-15$ & 46.56 & 22.17 & 24.39 & 1.17 \\
\hline & $15-30$ & 37.09 & 17.66 & 19.43 & 1.29 \\
\hline & $30-45$ & 35.55 & 16.92 & 18.63 & 1.35 \\
\hline & $45-60$ & 33.19 & 15.80 & 17.39 & 1.37 \\
\hline \multicolumn{2}{|c|}{ Mean } & 38.09 & 18.14 & 19.96 & 1.30 \\
\hline \multirow{4}{*}{$2010 / 2011$} & $0-15$ & 45.08 & 21.58 & 23.50 & 1.13 \\
\hline & $15-30$ & 37.95 & 18.04 & 19.91 & 1.24 \\
\hline & $30-45$ & 35.95 & 17.32 & 18.63 & 1.28 \\
\hline & $45-60$ & 33.14 & 16.04 & 17.10 & 1.32 \\
\hline \multicolumn{2}{|c|}{ Mean } & 38.03 & 18.25 & 19.79 & 1.24 \\
\hline
\end{tabular}

*Determined as described by Klute (1986).

Table (2). Some physical and chemical properties of the soil at the experimental site

\begin{tabular}{|c|c|c|c|c|c|c|c|c|c|c|}
\hline \multirow{3}{*}{ Season } & \multicolumn{3}{|c|}{ Particle size distribution* } & \multirow{3}{*}{$\begin{array}{c}\text { Textural } \\
\text { class }\end{array}$} & \multicolumn{6}{|c|}{ Chemical properties** } \\
\hline & Clay & Silt & Sand & & \multirow{2}{*}{$\begin{array}{l}\text { O.M. } \\
(\%)\end{array}$} & \multirow{2}{*}{$\mathrm{EC} \mathrm{dS} / \mathrm{m}$} & \multicolumn{3}{|c|}{ Available (ppm) } & \multirow[t]{2}{*}{$\mathrm{pH}$} \\
\hline & \multicolumn{3}{|c|}{$\%$} & & & & $\mathrm{~N}$ & $\mathrm{P}$ & K & \\
\hline $2008 / 2009$ & 49.90 & 33.80 & 16.30 & Clay & 2.20 & 0.43 & 45.00 & 12.5 & 202.5 & 7.9 \\
\hline $2009 / 2010$ & 50.29 & 32.38 & 17.33 & Clay & 2.04 & 0.56 & 41.02 & 10.0 & 198.8 & 7.8 \\
\hline $2010 / 2011$ & 48.49 & 32.41 & 19.10 & Clay & 1.57 & 0.38 & 37.0 & 11.0 & 183.8 & 8.1 \\
\hline
\end{tabular}

*According to Piper (1950)

**according to Ryan et al. (1996)

The data collected for the studied variables were subjected to statistical analysis using analysis of variance (ANOVA) technique (Senedecor and Cochran, 1980). The means were compared using least significant difference (LSD) at 5\% probability level according to Waller and Duncan (1969).

Crop - water relationships:

1- Seasonal consumptive use (ETC):

On determining the crop water consumptive use $\left(\mathrm{ET}_{\mathrm{C}}\right)$, soil samples were collected before and 48 hours after each irrigation, as well as at harvest time in $15 \mathrm{~cm}$ increment to $60 \mathrm{~cm}$ depth of the soil profile. The crop water consumptive use between two successive irrigations was calculated according to the equation given by Israelsen and Hansen (1962) expressed as:

$$
\mathrm{Cu}=\frac{\mathrm{D} \cdot \mathrm{Bd} \cdot[\mathrm{Q} 2-\mathrm{Q} 1]}{100}
$$

Where:

$\mathrm{Cu}=$ Actual evapotranspiration $(\mathrm{cm})$

$\mathrm{D}=$ Effective root zone depth $(\mathrm{cm})$.

Fayoum J. Agric. Res. \& Dev., Vol. 26, No.2, July, 2012 
$\mathrm{Bd}=$ Bulk density of soil $\left(\mathrm{gcm}^{-3}\right)$.

$\mathrm{Q} 2=$ Soil moisture content (\%) after irrigation.

$\mathrm{Q} 1=$ Soil moisture content $(\%)$ before the next irrigation.

\section{Water Productivity (WP):}

Water productivity is an efficiency term calculated as a ratio of product output over water input. The output could be biological goods such as crop grain, fodder....etc. So, water productivity, in the present study, is expressed as kgs of onion bulb yield obtained per the unit of irrigation water applied or consumed water basis. The water productivity values ( $\mathrm{kg}$ onion bulbs/ $\mathrm{m}^{3}$ applied water) and water use efficiency (WUE) were calculated for different treatments as follows:

$\mathrm{WP}\left(\mathrm{kg} / \mathrm{m}^{3}\right)=$ Bulbs yield $(\mathrm{kg} / \mathrm{fed}) /$ applied water $\left(\mathrm{m}^{3} / \mathrm{fed}\right)$.

Water use efficiency values (WUE, $\mathrm{kg} / \mathrm{m} 3$ ) were calculated according to the following equation (Vites, 1965): $\mathrm{WUE}=\mathrm{Kg}$ bulb $/ \mathrm{m}^{3}$ consumed

\section{Applied irrigation water}

$\mathrm{ET}_{\mathrm{c}} / \mathrm{E}_{\mathrm{a}}+\mathrm{LR}$

Where: $\mathrm{ET}_{\mathrm{c}}$ : water consumptive use $\quad \mathrm{E}_{\mathrm{a}}$ : application efficiency (fraction)

LR: Leaching requirements $(\mathrm{cm})$

\section{RESULTS AND DISCUSSION}

Applied irrigation water

Results in Table (3) reveal that as irrigation events increased, the applied water increased. In 2008/2009 season, the total amount of applied irrigation water for $\mathrm{I}_{4}$ were $243.6,122.1$, and $58.0 \%$ more than those of $\mathrm{I}_{1}, \mathrm{I}_{2}$ and $\mathrm{I}_{3}$, respectively. Similar trends were recorded in 2009/2010 and 2010/2011 seasons, where the increasing percentages for $\mathrm{I}_{4}$ were 226.7 and 234.6, 117.2 and 115.3 and 55.3 and 55.9, as compared with $\mathrm{I}_{1}, \mathrm{I}_{2}$ and $\mathrm{I}_{3}$ treatments, respectively. Results show that for $\mathrm{I}_{4}$ treatment, applied irrigation water varied from 2165 to $2205 \mathrm{~m}^{3}$ /fed. While, for $I_{1}$ treatment the same values varied from 630 to $675 \mathrm{~m}^{3} / \mathrm{fed}$. from season to another.

Table 3. Amounts of irrigation water $\left(\mathrm{m}^{3} / \mathrm{fed}\right.$.) applied under the adopted irrigation treatments in 2008/2009, 2009/2010 and 2010/2011 seasons

\begin{tabular}{|c|c|c|c|c|c|c|c|c|c|c|c|}
\hline \multirow{3}{*}{ Season } & \multicolumn{11}{|c|}{ Irrigation treatment } \\
\hline & $\mathrm{I}_{1}$ & \multicolumn{2}{|c|}{$\mathrm{I}_{2}$} & \multicolumn{3}{|c|}{$\mathrm{I}_{3}$} & \multicolumn{5}{|c|}{$\mathrm{I}_{4}$} \\
\hline & (TPI) & (TPI) & $(\mathrm{LI})$ & (TPI) & $(\mathrm{LI})$ & $\begin{array}{c}2^{\text {nd }} \\
\text { Irrigation }\end{array}$ & (TPI) & $(\mathrm{LI})$ & $\begin{array}{c}2^{\text {nd }} \\
\text { rrigation }\end{array}$ & $\begin{array}{c}3^{\text {rd }} \\
\text { Irrigation }\end{array}$ & $\begin{array}{c}4^{\text {th }} \\
\text { Irrigation }\end{array}$ \\
\hline $2008 / 2009$ & 630 & 630 & 345 & 630 & 345 & 395 & 630 & 345 & 395 & 410 & 385 \\
\hline $\begin{array}{c}\text { Applied } \\
\text { water }\end{array}$ & 630 & \multicolumn{2}{|c|}{975} & \multicolumn{3}{|c|}{1370} & \multicolumn{5}{|c|}{2165} \\
\hline $2009 / 2010$ & 675 & 675 & 340 & 675 & 340 & 405 & 675 & 340 & 405 & 415 & 370 \\
\hline $\begin{array}{l}\text { Applied } \\
\text { water }\end{array}$ & 675 & \multicolumn{2}{|c|}{1015} & \multicolumn{3}{|c|}{1420} & \multicolumn{5}{|c|}{2205} \\
\hline $\begin{array}{l}2010 / \\
2011\end{array}$ & 650 & 650 & 360 & 650 & 360 & 385 & 650 & 360 & 385 & 400 & 380 \\
\hline $\begin{array}{l}\text { Applied } \\
\text { water }\end{array}$ & 650 & \multicolumn{2}{|c|}{1010} & \multicolumn{3}{|c|}{1395} & \multicolumn{5}{|c|}{2175} \\
\hline
\end{tabular}

Fayoum J. Agric. Res. \& Dev., Vol. 26, No.2, July, 2012 
Growth charcters :-

Results in Table (4) illustrate that plant height, no. of leaves /plant and bulb diameter characters were significantly influenced by irrigation and onion varieties treatments. The plant height increased under $\mathrm{I}_{4}$ irrigation treatment by $90.3,46.7$ and $25.4 \%$, respectively, as compared with those under $I_{1}, I_{2}$ and $I_{3}$ in 2008/2009 season. The corresponding increasing values, in 2009/2010 and 2010/2011 seasons, reached (83.3 and 87.0\%), (48.4 and 53.7\%) and (24.6 and $20.6 \%$ ) for $I_{4}$ irrigation treatment, as compared with those under $I_{1}, I_{2}$ and $I_{3}$ treatments, respectively.

Regarding the impacts of the adopted onion varieties on plant height trait, results in Table (4) indicate in 2008/2009 season that Giza Red variety is the superior in this respect since average plant height values increased by 20.90 and $3.96 \%$ more than those for Giza 6 Mohassan and Giza 20 onion varieties, respectively. In 2009/2010 and 2010/2011 seasons, similar trends were noticed with increased plant height values for Giza Red variety comprised (21.25and $18.18 \%$ ) and (10.03 and $5.98 \%$ ), respectively, more than those for Giza 6 Mohassan and Giza 20 onion varieties. Results in Table (4) show clearly that Giza Red variety still surpassed both Giza 6 Mohassan and Giza 20 varieties with respect to no. of leaves/plant character where the increasing percentage reached 25.5 and $8.0 \%$, respectively, in 2008/2009 season. Similar trends were noticed in 2009/2010 and 2010/2011 seasons where the increasing percentages in no. of leave/plant character for Giza Red variety comprised (26.4and $28.2 \%$ ) and (8.0 and $11.4 \%$ ), respectively as compared with Giza 6 Mohassan and Giza 20. Generally, in the three seasons, mid values of bulb diameter for Giza 6 Mohasson and Giza 20 cultivars, respectively.

Under $\mathrm{I}_{4}$ irrigation treatment, in 2008/2009 season, no. of leave/plant increased by $118.6,105.2$ and $12.1 \%$ more than those under $I_{1}, I_{2}$ and $I_{3}$ treatments, respectively. In 2009/2010 and 2010/2011 seasons similar trend was observed where the increase in no. of leave /plant under $\mathrm{I}_{4}$ irrigation treatment was (117.0 and111.1\%), (102.8 and 99.1\%) and (16.2 and 14.1\%), respectively as compared with those under $\mathrm{I}_{1}, \mathrm{I}_{2}$ and $\mathrm{I}_{3}$ treatments. In connection, Satyendra et al. (2007) stated that irrigation had significant effect on growth parameters of onion.

In the first season, bulb diameter was increased under $\mathrm{I}_{4}$ irrigation by $76.9,82.9$ and $24.3 \%$ more than those of $\mathrm{I}_{1}, \mathrm{I}_{2}$ and $\mathrm{I}_{3}$ treatments, respectively. In 2009/2010 and 2010/2011 seasons, similar trend was observed where the increase in bulb diameter under $\mathrm{I}_{4}$ irrigation treatment was $(50.0$ and $71.6 \%)$, (44.7 and 69.5\%) and (11.5 and 29.1\%), respectively as compared with those under $\mathrm{I}_{1}, \mathrm{I}_{2}$ and $\mathrm{I}_{3}$ treatments.

Interaction of the adopted treatments did not exert any effect to influence onion plant height trait and such trend was true in 3 consecutive growing seasons Table (4) nevertheless, Giza red onion variety as interacted with $\mathrm{I}_{4}$ irrigation treatment exhibited significant effect to increase no. of leave/plant in the 3 consecutive seasons, and in the $1^{\text {st }} \& 3^{\text {rd }}$ seasons for bulb diameter character. 
EVALUATING THE EFFECT OF IRRIGATION NUMBER ON......

Table 4. Interaction effect of irrigation treatments and onion cultivars on plant height, leaves number / plant and bulb diameter in 2008/2009, 2009/2010 and 2010 / 2011 seasons.

\begin{tabular}{|c|c|c|c|c|c|c|c|c|c|c|}
\hline \multirow{2}{*}{$\begin{array}{c}\text { Irrigation } \\
\mathrm{A}\end{array}$} & \multirow{2}{*}{$\begin{array}{c}\text { Varieties } \\
\text { B }\end{array}$} & \multicolumn{3}{|c|}{ Plant height $(\mathrm{cm})$} & \multicolumn{3}{|c|}{ N. of leaves / plant } & \multicolumn{3}{|c|}{ Bulb diameter $(\mathrm{cm})}$. \\
\hline & & $1 \stackrel{\text { st }}{ }$ & $2^{\text {nd }}$ & $3^{\text {rd }}$ & $1 \stackrel{\text { st }}{ }$ & $2^{\frac{\mathrm{nd}}{-}}$ & $3 \stackrel{\text { rd }}{-}$ & $1^{\mathrm{st}}$ & $2^{\text {nd }}$ & $3^{\text {rd }}$ \\
\hline \multirow{3}{*}{$\mathrm{I}_{1}$} & $\mathrm{~V}_{1}$ & 29.43 & 31.60 & 31.63 & 5.58 & 5.93 & 5.50 & 3.35 & 3.15 & 3.15 \\
\hline & $\mathrm{V}_{2}$ & 38.73 & 40.60 & 39.80 & 6.35 & 6.40 & 6.43 & 3.48 & 3.63 & 3.55 \\
\hline & $\mathrm{V}_{3}$ & 40.73 & 41.68 & 40.90 & 7.00 & 7.13 & 7.00 & 3.15 & 3.13 & 3.33 \\
\hline \multicolumn{2}{|c|}{ Mean } & 36.29 & 37.96 & 37.44 & 6.31 & 6.48 & 6.31 & 3.33 & 3.30 & 3.34 \\
\hline \multirow{3}{*}{$\mathrm{I}_{2}$} & $\mathrm{~V}_{1}$ & 39.83 & 42.20 & 41.20 & 6.10 & 6.38 & 5.95 & 3.05 & 3.20 & 3.25 \\
\hline & $\mathrm{V}_{2}$ & 49.35 & 46.63 & 44.42 & 6.95 & 7.25 & 7.05 & 3.28 & 3.55 & 3.38 \\
\hline & $\mathrm{V}_{3}$ & 52.05 & 51.85 & 51.05 & 7.10 & 6.95 & 7.05 & 3.33 & 3.50 & 3.53 \\
\hline \multicolumn{2}{|c|}{ Mean } & 47.08 & 46.89 & 45.56 & 6.72 & 6.86 & 6.68 & 3.22 & 3.42 & 3.38 \\
\hline \multirow{3}{*}{$\mathrm{I}_{3}$} & $\mathrm{~V}_{1}$ & 49.05 & 49.78 & 51.33 & 10.15 & 9.98 & 9.85 & 4.28 & 3.88 & 4.03 \\
\hline & $\mathrm{V}_{2}$ & 56.68 & 53.78 & 60.05 & 12.43 & 11.73 & 11.55 & 4.83 & 4.60 & 4.43 \\
\hline & $\mathrm{V}_{3}$ & 59.50 & 64.00 & 62.83 & 14.28 & 14.15 & 13.58 & 5.13 & 4.85 & 4.88 \\
\hline \multicolumn{2}{|c|}{ Mean } & 55.08 & 55.85 & 58.07 & 12.28 & 11.95 & 11.66 & 4.74 & 4.44 & 4.44 \\
\hline \multirow{3}{*}{$\mathrm{I}_{4}$} & $\mathrm{~V}$ & 66.38 & 66.75 & 67.93 & 12.48 & 11.98 & 11.88 & 5.10 & 4.60 & 5.30 \\
\hline & $\mathrm{V}_{2}$ & 69.90 & 68.72 & 69.93 & 14.15 & 14.65 & 13.13 & 6.08 & 5.00 & 5.45 \\
\hline & $\mathrm{V}_{3}$ & 70.88 & 73.22 & 72.22 & 14.70 & 15.05 & 14.90 & 6.50 & 5.25 & 6.45 \\
\hline \multicolumn{2}{|c|}{ Mean } & 69.05 & 69.57 & 70.03 & 13.78 & 13.89 & 13.30 & 5.89 & 4.95 & 5.73 \\
\hline \multirow{3}{*}{$\begin{array}{l}\text { Mean over } \\
\text { Varity }\end{array}$} & $\mathrm{V}_{1}$ & 46.17 & 47.58 & 48.02 & 8.58 & 8.57 & 8.29 & 3.94 & 3.71 & 3.93 \\
\hline & $\mathrm{V}_{2}$ & 53.66 & 52.43 & 53.55 & 9.97 & 9.96 & 9.54 & 4.41 & 4.19 & 4.20 \\
\hline & $\mathrm{V}_{3}$ & 55.79 & 57.69 & 56.75 & 10.77 & 10.77 & 10.63 & 4.53 & 4.18 & 4.54 \\
\hline \multirow{3}{*}{$\begin{array}{l}\text { Interaction } \\
\text { L.S.D at } 5 \%\end{array}$} & $\mathrm{~A}$ & 3.05 & 2.63 & 3.375 & 1.157 & 0.690 & 0.461 & 0.308 & 0.436 & 0.351 \\
\hline & B & 2.56 & 3.80 & 4.666 & 0.557 & 0.838 & 0.735 & 0.177 & 0.398 & 0.264 \\
\hline & $A * B$ & $\mathrm{NS}$ & 3.92 & $\mathrm{NS}$ & 0.850 & 0.980 & 0.830 & 0.497 & $\mathrm{NS}$ & 0.494 \\
\hline
\end{tabular}

In Table (5) results of, bulb weight showed that, increasing no. of irrigations tended to increase such trait, where the values for $\mathrm{I}_{4}$ irrigation treatment were 95.2, 57.3 and $31.2 \%$ more than those under $\mathrm{I}_{1}, \mathrm{I}_{2}$ and $\mathrm{I}_{3}$ treatments, respectively, in 2008/2009 season. The corresponding increase values in 2009/2010 and 2010/2011 seasons comprised (110.0 and 101.1\%), (63.5 and 63.8\%) and (39.8 and 31.6\%), respectively, in the same order. In connection, Satyendra et al. (2007) found that higher irrigation rate (irrigation at 1.20 pan evaporation) produced higher bulb size and weight means, which decreased with the decrease in amount of irrigation. In addition, El-Akram (2012) in Egypt, stated that onion bulb yield was higher with 8 irrigation events, in comparison with 6 and 7 irrigation treatments.

As for bulb weight trait, in 2008/2009 season, Giza Red variety still the superior with increase values reached 14.8 and $1.9 \%$ more than those for Giza 6 Mohassan and Giza 20 onion varieties, respectively. Similar trends were noticed in 2009/2010 and 2010/2011 seasons where the increase values were (7.1 and 1.1\%) and (15.6 and 5.6\%), respectively, in the same order.

Fayoum J. Agric. Res. \& Dev., Vol. 26, No.2, July, 2012 
Table 5. Bulb weight, dry matter $\%$ and maturity for onion cultivars as effected by irrigation treatments in 2008/2009, 2009/2010 and 2010 / 2011 seasons.

\begin{tabular}{|c|c|c|c|c|c|c|c|c|c|c|}
\hline \multirow{2}{*}{\begin{tabular}{|c|} 
Irrigation \\
Counts "A"
\end{tabular}} & \multirow{2}{*}{$\begin{array}{c}\text { Varieties } \\
\text { "B" }\end{array}$} & \multicolumn{3}{|c|}{ Bulb weight (g) } & \multicolumn{3}{|c|}{ Dry mater \% } & \multicolumn{3}{|c|}{ Days to maturity } \\
\hline & & $1 \stackrel{\mathrm{st}}{\mathrm{s}}$ & $2^{\text {nd }}$ & $3^{\text {rd }}$ & $1 \stackrel{\text { st }}{ }$ & $2^{\text {nd }}$ & $3^{\text {rd }}$ & $1 \stackrel{\text { st }}{ }$ & $2^{\text {nd }}$ & $3^{\text {rd }}$ \\
\hline \multirow[t]{3}{*}{$\mathrm{I}_{1}$} & $\mathrm{~V}_{1}$ & 42.96 & 42.30 & 44.01 & 16.20 & 16.48 & 16.40 & 107.25 & 108.75 & 106.00 \\
\hline & $\mathrm{V}_{2}$ & 48.39 & 47.29 & \begin{tabular}{|l|}
46.91 \\
\end{tabular} & 14.78 & 14.68 & 14.80 & 117.50 & 119.25 & 118.25 \\
\hline & $\mathrm{V}_{3}$ & 55.61 & 50.72 & 50.11 & 14.30 & 13.98 & 13.98 & 116.75 & 120.75 & 123.00 \\
\hline \multicolumn{2}{|c|}{ Mean } & 48.99 & 46.77 & 47.01 & 15.09 & 15.04 & 15.06 & 113.83 & 116.25 & 115.75 \\
\hline \multirow[t]{3}{*}{$\mathrm{I}_{2}$} & $\mathrm{~V}_{1}$ & 58.02 & 58.13 & 52.76 & 17.05 & 16.20 & 16.95 & 107.50 & 106.50 & 107.00 \\
\hline & $\mathrm{V}_{2}$ & 62.65 & 61.17 & 59.79 & 15.01 & 15.05 & 14.75 & 117.25 & 118.75 & 116.75 \\
\hline & $\mathrm{V}_{3}$ & 61.76 & 60.95 & 62.38 & 14.13 & 14.45 & 14.15 & 121.75 & 120.00 & 123.25 \\
\hline \multicolumn{2}{|c|}{ Mean } & 60.81 & 60.08 & 58.31 & 15.40 & 15.23 & 15.28 & 115.50 & 115.08 & 115.67 \\
\hline \multirow[t]{3}{*}{$\mathrm{I}_{3}$} & $\mathrm{~V}_{1}$ & 62.04 & 63.15 & 64.78 & 16.30 & 15.25 & 15.73 & 120.75 & 120.75 & 123.25 \\
\hline & $\mathrm{V}_{2}$ & 79.87 & 73.93 & \begin{tabular}{|l|}
74.67 \\
\end{tabular} & 14.20 & 14.23 & 14.18 & 128.75 & 128.75 & 129.25 \\
\hline & $\mathrm{V}_{3}$ & 76.87 & 73.74 & \begin{tabular}{|l|}
78.37 \\
\end{tabular} & 14.25 & 14.38 & 14.70 & 130.00 & 129.75 & 132.00 \\
\hline \multicolumn{2}{|c|}{ Mean } & 72.93 & 70.27 & 72.61 & 14.92 & 14.62 & 14.87 & 126.50 & 126.42 & 128.18 \\
\hline \multirow[t]{3}{*}{$\mathrm{I}_{4}$} & $\mathrm{~V}_{1}$ & 91.98 & 91.71 & 91.44 & 14.88 & 14.83 & 14.95 & 123.75 & 125.75 & 123.75 \\
\hline & $\mathrm{V}_{2}$ & 96.33 & 101.5 & 93.51 & 13.30 & 13.48 & 13.63 & 146.25 & 151.25 & 143.75 \\
\hline & $\mathrm{V}_{3}$ & 98.63 & 101.5 & 102.68 & 13.43 & 13.18 & 13.20 & 147.50 & 150.25 & 150.25 \\
\hline \multicolumn{2}{|c|}{ Mean } & 95.65 & 98.24 & 95.54 & 13.87 & 13.83 & 13.93 & 139.17 & 142.42 & 139.25 \\
\hline \multirow{3}{*}{$\begin{array}{c}\text { Mean over } \\
\text { Cultivars }\end{array}$} & $\mathrm{V} 1$ & 63.75 & 63.82 & 63.25 & 16.11 & 15.69 & 16.01 & 114.81 & 115.44 & 115.00 \\
\hline & $\mathrm{V} 2$ & \begin{tabular}{|l|}
71.81 \\
\end{tabular} & 70.97 & 68.71 & 14.33 & 14.36 & 14.34 & 127.44 & 129.50 & 127.00 \\
\hline & V 3 & 73.22 & 71.72 & 73.13 & 14.03 & 13.99 & 14.01 & 129.00 & 130.19 & 132.13 \\
\hline \multirow{3}{*}{$\begin{array}{l}\text { Interaction } \\
\text { L.S.D at } 5 \%\end{array}$} & A & 6.364 & 8.87 & 3.113 & 0.531 & 0.555 & 0.598 & 2.438 & 3.514 & 3.521 \\
\hline & $B$ & 4.180 & NS & 2.974 & 0.919 & 0.550 & 0.301 & 3.374 & 4.128 & 3.801 \\
\hline & $\mathrm{A} * \mathrm{~B}$ & $\mathrm{NS}$ & $\mathrm{NS}$ & $\mathrm{NS}$ & $\mathrm{NS}$ & NS & $\mathrm{NS}$ & 5.209 & 3.614 & 4.771 \\
\hline
\end{tabular}

On the other hand, in Table (5) illustrate that dry matter percentage were significantly influenced by irrigation, in the 3 seasons. Dry matter persentage decreased with increasing number of irrigations; may by there is relation between declivity dry matter \% with increasing water in bulb by irrigations. The interaction did not significant effect on dry matter percentage in 3 seasons.

Data in Table (5) showed that days to maturity increased by increasing number of irrigations, and lack of irrigation advanced bulb maturity. Onion plants were significantly influenced due to adopted irrigation and varieties. Height maturing seemed to increase under $\mathrm{I}_{4}$ irrigation treatment by 22.3, 20.5, and $10.0 \%$, respectively as compared with those $I_{1}, I_{2}$ and $I_{3}$ in 2008/2009 season. The corresponding increase values in 2009/2010 and 2010/2011 seasons, reached (22.5 and 20.3\%), (23.5 and 20.4\%) and (12.7 and 8.6\%) under $\mathrm{I}_{4}$ irrigation treatment, comparable with those under $\mathrm{I}_{1}, \mathrm{I}_{2}$ and $\mathrm{I}_{3}$ ones, respectively. Giza 6 Mohassan was early cultivar than the others. The interaction between irrigation with cultivars was significantly affected, Giza 6 Mohassan with $I_{1}$ and $I_{2}$ gave short life (106 days) compared with Giza red cultivar under $\mathrm{I}_{4}$ gave the highest value of maturing (150.25 days), it might be due to moisture stress in this treatment have adversely affected the cell division and cell enlargement because of reduction in the level of endogenous phytohormones viz., auxins (Nandi et al 2002) and Abd El- Gawwed (2008).

Data in Table (5) indicate that Giza red variety as interacted with $\mathrm{I}_{4}$ irrigation treatment exhibited the highest figures for bulb diameter and bulb weight attributes in 3 successive seasons.

Fayoum J. Agric. Res. \& Dev., Vol. 26, No.2, July, 2012 


\section{Marketable culls and total bulb yields}

Data in Table (6) reveal that both marketable and culls onion bulb yields were significantly affected due to the adopted irrigation treatments in 3 successive seasons of study. Regardless onion varieties, increasing the applied irrigation water under $\mathrm{I}_{4}$ treatment seemed to increase marketable bulb onion yield, in 2008/2009 season, by 119.3, 76.1 and 32.8\% more than those recoded with $\mathrm{I}_{1}, \mathrm{I}_{2}$ and $\mathrm{I}_{3}$ irrigation treatments, respectively. Similar trends were observed in 2009/2010 and 2010/2011 seasons where the increases, in the marketable bulb yield under $\mathrm{I}_{4}$, were (109.0 and $\left.118.2 \%\right),(104.8$ and $69.8 \%)$ and $\left(26.8\right.$ and $51.8 \%$ ) higher than those with $\mathrm{I}_{1}, \mathrm{I}_{2}$ and $\mathrm{I}_{3}$ ones, respectively. Regarding culls onion bulb yield, irrigation treatments exhibited similar trend to that of marketable onion bulb yield (Table 6). Onion culls bulb yield seemed to increase under irrigation treatment $\left(\mathrm{I}_{4}\right)$, in $2008 / 2009$ season, by $54.1,32.5$ and $29.2 \%$ more than those recoded with $\mathrm{I}_{1}, \mathrm{I}_{2}$ and $\mathrm{I}_{3}$ irrigation treatments, respectively. Similar trends were observed in 2009/2010 and $2010 / 2011$ seasons where the increases, in culls bulb yield under $\mathrm{I}_{4}$, were (71.0and 44.9\%), (46.0and 42.2\%) and (32.7and 9.0\%) higher than those with $\mathrm{I}_{1}, \mathrm{I}_{2}$ and $\mathrm{I}_{3}$ ones, respectively. It is worthy to mention that marketable onion yield, as \% out of total onion bulb yield, seemed to increase as applied water increased, where the \%values ranged (84.5-86.1), (77.3-85.2), (79-84.4) and (78.2-80.3) under $\mathrm{I}_{4}, \mathrm{I}_{3}, \mathrm{I}_{2}$ and $\mathrm{I}_{1}$ irrigation treatments, respectively in 3 successive seasons. Regarding total bulb yield, irrigating according to $\mathrm{I}_{4}$ resulted in higher values reached 104.6, 67.8 and 30.3\% higher than those recoded with $I_{1}, I_{2}$ and $I_{3}$ irrigation treatments, respectively. Similar trends were noticed in 2009/2010 and 2010/2011 seasons where the increases, in total bulb yield under $\mathrm{I}_{4}$, were (91.9 and $\left.102.1 \%\right)$, (86.7 and $\left.69.5 \%\right)$ and $(24.5$ and $38.90 \%$ ) greater than those with $\mathrm{I}_{1}, \mathrm{I}_{2}$ and $\mathrm{I}_{3}$ ones, respectively, however, the differences did not significance level in 2009/2010 season.

Higher figures for marketable, culls and total bulb onion yields under $\mathrm{I}_{4}$ irrigation treatment may be owing to better growth performance of onion varieties resulting from optimize soil moisture status in the root zone which encourage water and nutrients absorption and consequently higher onion bulb yields. In this sense, Pelter et al. (2004) stated that soil-water stress caused by withholding irrigation at both the 3- and 7-leaf stages reduced onion yields by 26\%, compared with the control. Moreover, Satyendra et al. (2007) found that onion yield was significantly affected by irrigation. In addition, ElAkram (2012) in Egypt, found that onion bulb yield was higher with frequently irrigation i.e. irrigating as $40 \%$ of available soil moisture was depleted, in comparison with irrigation at 60 and $80 \%$ ones.

Regarding onion varieties, Giza Red onion variety exhibited the highest marketable onion yield values in 3 successive seasons reached 13.5 and $2.4 \%$ greater than those with Giza 6 Mohassan, Giza 20 ones, respectively, in 2008/2009 season. Similar trends were obtained in 2009/2010 and 2010/2011 seasons with increase values, for Giza red variety, comprised (21.0 and 5.2\%) and (20.6 and 10.8\%), respectively, comparable with Giza 6 Mohassan and Giza 20 ones. As for culls onion yield as influenced by the onion varieties, in 2008/2009 and 2009/2010 seasons Giza red onion variety had lower values reached (15.2 and 14.8\%) and (8.2 and 3.3\%) less than those with Giza 6 Mohassan and Giza 20 ones, respectively. Nevertheless, in 2010/2011 season the trend was reversed since Giza Red onion variety exhibited higher culls

Fayoum J. Agric. Res. \& Dev., Vol. 26, No.2, July, 2012 
onion yield values comprised 35.0 and $4.4 \%$ greater than those reported for Giza 6 Mohassan and Giza 20 ones, respectively.

With respect to total onion yield, Giza Red onion variety exhibited higher values where the increases were (13.7 and 6.3\%), (20.4 and 3.7\%) and (22.8 and 9.4\%) more than those recorded for Giza 6 Mohassan and Giza 20 varieties, respectively, in 2008/2009, 2009/2010 and 2010/2011 seasons. Data in Table (6) prove that interaction of the adopted irrigation treatments and onion varieties reveal an inconsistent trend to influence marketable, culls and total bulb yields in 3 successive seasons.

Table 6. Marketable, culls and total bulb yields (tons/fed.) for onion cultivars as affected by irrigation treatments in 2008/2009, $2009 / 2010$ and $2010 / 2011$ seasons

\begin{tabular}{|c|c|c|c|c|c|c|c|c|c|c|}
\hline \multirow{2}{*}{$\begin{array}{l}\text { Irrigation } \\
\text { Counts "A" }\end{array}$} & \multirow{2}{*}{$\begin{array}{c}\text { Varieties } \\
\text { "B" }\end{array}$} & \multicolumn{3}{|c|}{$\begin{array}{l}\text { Marketable yield } \\
\text { (tons/fed) }\end{array}$} & \multicolumn{3}{|c|}{$\begin{array}{c}\text { Culls yield } \\
\text { (tons/fed) }\end{array}$} & \multicolumn{3}{|c|}{$\begin{array}{c}\text { Total yield } \\
\text { (tons/fed) }\end{array}$} \\
\hline & & $1 \stackrel{\mathrm{st}}{\mathrm{st}}$ & $2^{\text {nd }}$ & $3 \stackrel{\text { rd }}{-}$ & $1 \stackrel{\text { st }}{1}$ & $2^{\frac{\text { nd }}{2}}$ & $3^{\mathrm{rd}}$ & $1^{\mathrm{st}}$ & $2^{\text {nd }}$ & $3^{\text {rd }}$ \\
\hline \multirow[t]{3}{*}{$P_{1}$} & $\overline{V_{1}}$ & $\begin{array}{l}5.17 \\
\end{array}$ & 5.26 & $\begin{array}{l}4.97 \\
\end{array}$ & 1.22 & 1.35 & 1.53 & 6.39 & 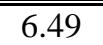 & 6.50 \\
\hline & $\mathrm{V}_{2}$ & 5.78 & 6.15 & 6.04 & 1.64 & 1.44 & 1.69 & 7.42 & $\begin{array}{l}7.87 \\
\end{array}$ & 7.73 \\
\hline & $\mathrm{V}_{3}$ & 6.76 & 5.92 & 6.14 & 1.20 & 1.66 & 1.54 & 7.96 & 7.49 & 7.68 \\
\hline \multicolumn{2}{|c|}{ Mean } & 5.90 & 5.77 & 5.71 & 1.35 & 1.48 & 1.58 & 7.25 & 7.25 & 7.30 \\
\hline \multirow[t]{3}{*}{$\mathrm{I}_{2}$} & $\overline{V_{1}}$ & 6.92 & $\bar{~} 5.15$ & 6.42 & $\begin{array}{l}1.39 \\
\end{array}$ & 1.23 & 1.36 & 88.31 & \begin{tabular}{c|c|c|}
6.38 \\
\end{tabular} & $\begin{array}{l}7.78 \\
\end{array}$ \\
\hline & $\overline{V_{2}}$ & $\begin{array}{l}7.38 \\
\end{array}$ & 6.19 & 7.04 & 1.63 & 1.72 & 1.63 & 99.01 & 7.63 & 8.67 \\
\hline & $\mathrm{V}_{3}$ & 7.76 & 6.33 & 8.56 & 1.68 & 1.57 & 1.86 & 9.44 & 7.99 & 10.42 \\
\hline \multicolumn{2}{|c|}{ Mean } & 7.35 & 5.89 & 7.34 & 1.57 & 1.50 & 1.61 & 8.92 & 7.45 & 8.70 \\
\hline \multirow[t]{3}{*}{$\mathrm{I}_{3}$} & $\overline{V_{1}}$ & 8.35 & 8.23 & 8.34 & 1.55 & 1.65 & 1.62 & 9.90 & $\begin{array}{l}9.88 \\
\end{array}$ & 9.96 \\
\hline & $\mathrm{V}_{2}$ & 10.27 & 9.73 & 7.43 & 1.77 & 1.79 & 2.28 & 12.04 & 11.52 & 9.71 \\
\hline & $\mathrm{V}_{3}$ & 10.61 & \begin{tabular}{|l|l}
10.59 \\
\end{tabular} & 8.88 & 1.50 & 1.51 & 2.41 & 12.11 & 12.10 & 11.29 \\
\hline \multicolumn{2}{|c|}{ Mean } & 9.74 & 9.52 & 88.21 & $\begin{array}{ll}1.61 \\
\end{array}$ & 1.65 & 2.10 & 11.34 & 211.17 & 10.62 \\
\hline \multirow[t]{3}{*}{$\mathrm{I}_{4}$} & $\mathrm{~V}_{1}$ & 12.81 & 11.02 & 11.00 & 1.64 & 1.92 & 1.81 & 14.45 & 12.94 & 12.81 \\
\hline & $\mathrm{V}_{2}$ & 13.41 & \begin{tabular}{|l|l}
12.09 \\
\end{tabular} & 12.94 & 2.27 & 2.34 & 2.50 & 14.87 & 14.43 & 15.44 \\
\hline & $\mathrm{V}_{3}$ & 12.60 & 13.06 & 13.45 & 2.33 & 2.31 & 2.65 & 15.74 & 15.37 & 16.10 \\
\hline \multicolumn{2}{|c|}{ Mean } & 12.94 & 12.06 & $\begin{array}{ll}12.46 \\
\end{array}$ & 2.08 & 2.19 & 2.29 & 15.05 & 13.91 & 14.75 \\
\hline \multirow{4}{*}{$\begin{array}{l}\text { Mean over } \\
\text { Cultivars }\end{array}$} & $\mathrm{V}_{1}$ & 8.31 & 7.42 & 7.91 & 1.45 & 1.54 & 1.58 & 9.76 & 8.95 & 9.55 \\
\hline & $\mathrm{V}_{2}$ & 9.21 & 8.54 & 8.34 & 1.84 & 1.82 & 2.03 & 11.04 & 10.36 & 10.36 \\
\hline & $\mathrm{V}_{3}$ & 9.34 & 8.98 & 9.02 & 1.66 & 1.76 & 2.09 & 11.11 & 10.49 & 11.12 \\
\hline & $\overline{\mathrm{A}}$ & 0.671 & 0.848 & 0.901 & 0.182 & 0.233 & 0.271 & 0.743 & 0.988 & 1.047 \\
\hline \multirow{2}{*}{$\begin{array}{l}\text { Interaction } \\
\text { L.S.D at 5\% }\end{array}$} & B & 0.543 & 0.387 & 0.999 & 0.144 & 0.184 & 0.186 & 0.871 & 0.642 & 0.871 \\
\hline & $\mathrm{A} * \mathrm{~B}$ & 1.010 & NS & NS & 0.312 & NS & 0.272 & NS & NS & NS \\
\hline
\end{tabular}

Onion- water relationships:

1- Water consumptive use (WCU)

Results in Table (7) reveal that, regardless onion variety, the highest water consumptive use values resulted from $\mathrm{I}_{4}$ treatment (5 irrigations) the three consecutive growing seasons. In 2008/2009 season, the increase in water consumptive use for crop due to $\mathrm{I}_{4}$ irrigation treatment reached 236.12, 146.95, $56.60 \%$, more than those recorded under $\mathrm{I}_{1}, \mathrm{I}_{2}$ and $\mathrm{I}_{3}$ treatments, respectively. Similar trends were observed in 2009/2010 and 2010/2011 seasons. The corresponding WCU increasing values for $\mathrm{I}_{4}$ treatment were $(273.1$ and $230.9 \%),(104.8$ and $113.0 \%)$ and (55.0 and $55.9 \%)$, respectively as compared with those of $\mathrm{I}_{1}, \mathrm{I}_{2}$ and $\mathrm{I}_{3}$ treatments. These results may be due to more

Fayoum J. Agric. Res. \& Dev., Vol. 26, No.2, July, 2012 
EVALUATING THE EFFECT OF IRRIGATION NUMBER ON......

available soil moisture under more frequent irrigation (i.e. $\mathrm{I}_{4}$ ). In connection, Abu-Awwad (1999) stated that increasing applied irrigation water significantly increased evapotranspiration and/or transpiration for onion crop. Furthermore, Kadayifci et al.,(2005) found that high water use for onion was observed with increasing levels of irrigation. In addition, El-Akram (2012) in Egypt, found that onion crop evapotranspiration (ETc) was higher with frequent irrigation, i.e. irrigating as $40 \%$ of available soil moisture was depleted in comparison with irrigation at 60 and $80 \%$ depletion treatments.

Table 7. Water consumptive use $(\mathrm{m} 3 /$ fed) by onion varieties as affected by irrigation treatments in 2008/2009, 2009/2010 and 2010/ 2011 seasons

\begin{tabular}{|c|c|c|c|c|c|c|c|c|c|c|c|c|}
\hline \multirow{3}{*}{ 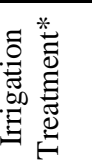 } & \multicolumn{4}{|c|}{$2008 / 2009$} & \multicolumn{4}{|c|}{$2009 / 2010$} & \multicolumn{4}{|c|}{ 2010/2011 } \\
\hline & \multicolumn{3}{|c|}{ Onion variety** } & \multirow{2}{*}{ Mean } & \multicolumn{3}{|c|}{ Onion variety** } & \multirow{2}{*}{ Mean } & \multicolumn{3}{|c|}{ Onion variety** } & \multirow{2}{*}{ Mean } \\
\hline & $\mathrm{V}_{1}$ & $\mathrm{~V}_{2}$ & $\mathrm{~V}_{3}$ & & $\mathrm{~V}_{1}$ & $\mathrm{~V}_{2}$ & $\mathrm{~V}_{3}$ & & $\mathrm{~V}_{1}$ & $\mathrm{~V}_{2}$ & $\mathrm{~V}_{3}$ & \\
\hline $\mathrm{I}_{1}$ & 379.5 & 389.5 & 400.5 & 389.83 & 421.9 & 412.6 & 234.9 & 356.5 & 391.6 & 401.2 & 397.6 & 396.8 \\
\hline $\mathrm{I}_{2}$ & 587.3 & 595.1 & 409.4 & 530.60 & 611.4 & 674.7 & 662.7 & 649.6 & 608.4 & 623.5 & 617.5 & 616.5 \\
\hline $\mathrm{I}_{3}$ & 825.3 & 839.2 & 845.7 & 836.73 & 855.4 & 861.4 & 858.4 & 858.4 & 840.4 & 843.4 & 842.8 & 842.2 \\
\hline $\mathrm{I}_{4}$ & 1304.0 & 1310.0 & 1317.0 & 1310.33 & 1328.3 & 1331.3 & 1330.7 & 1330.1 & 1310.2 & 1316.3 & 1312.7 & 1313.1 \\
\hline Mean & 774.03 & 783.45 & 743.15 & 766.88 & 804.3 & 820.0 & 771.7 & 798.7 & 787.7 & 796.1 & 792.6 & 792.1 \\
\hline
\end{tabular}

Regardless the adopted irrigation treatments, results in Table (7) reveal that, in 2008/2009 season, Giza 20 onion varieties exhibited the highest water consumptive use values which were 1.22 and $5.42 \%$ more than those recorded for Giza 6 Mohassan and Giza red ones, respectively. In 2009/2010 and $2010 / 2011$ seasons, the same trend was reported and the respected values were 1.95 and $6.26 \%$ and 1.07 and $0.44 \%$ in the same order.

Results show that there were no major differences between water consumption by the three varieties. Average water consumptive use values for Giza 6 Mohassan varied between 397 and $1314 \mathrm{~m}^{3} / \mathrm{fed}$. For the $\mathrm{I}_{1}$ and $\mathrm{I}_{4}$ irrigation treatments, respectively. The same respective values for Giza 20 were between 401 and $1319 \mathrm{~m}^{3} /$ fed. and were 407 and a320 m $/$ fed. for Giza red onion.

\section{2- Water use efficiency (WUE) and water productivity (WP)}

Results in Table (8) show that, regardless onion varieties, as values of water consumed or water applied increased the marketable bulb yield decreased. In 2008/2009 season, the increased in WP values under $I_{1}$ irrigation treatment were 5.1, 29.8 and 52.9\% as compared with those under $\mathrm{I}_{2}, \mathrm{I}_{3}$ and $\mathrm{I}_{4}$ treatments, respectively. Similar trends were observed in 2009/2010 and 2010/2011 seasons with increasing percentages that reached (58.0 and 22.9), (93.6 and 49.8) and (93.4 and 54.1), respectively, in the same order. The obtained results agreed with those reported by Abu-Awwad (1999) and Kadayifci et al., (2005) they stated that water use efficiency for onion was maximum for the highest water level treatment. In connection, El-Akram (2012) in Egypt, found that water use efficiency was slightly higher with, more frequent irrigation, i.e. irrigating as $40 \%$ of available soil moisture was depleted, in comparison with irrigation at 60 and $80 \%$ ones.

Results show also that Giza red onion variety proved to use the water more efficiently than Giza 6 Mohassan and Giza 20 varieties in the three

Fayoum J. Agric. Res. \& Dev., Vol. 26, No.2, July, 2012 
successive growing seasons. The increase in WP values for Giza red variety were 27.8 and $16.6 \%$ more than those recorded for Giza 6 Mohassan and Giza 20 , respectively in 2008/2009 season. In 2009/2010 and 2010/2011 seasons, similar trends were noticed with increasing values comprised (46.7 and $28.1 \%$ ) and (22.2 and $12.9 \%)$, respectively.

Under the conditions of the present experiment and to conserve the limited irrigation water resources, as an important national issue, it is advisable to grow Giza red onion variety under the $I_{3}$ irrigation treatment in order to obtain reasonable water productivity and water saving.

Table (8). Water use efficiency $(\mathrm{Kg} / \mathrm{m3}$ consumed water) and water productivity $(\mathrm{Kg} / \mathrm{m} 3$ applied water) as affected by the adopted treatments in $2008 / 2009$, $2009 / 2010$ and $2010 / 2011$ seasons

\begin{tabular}{|c|c|c|c|c|c|c|c|}
\hline \multirow{2}{*}{ Irrigation } & \multirow{2}{*}{ Variety } & \multicolumn{2}{|c|}{$2008 / 2009$} & \multicolumn{2}{|c|}{$2009 / 2010$} & \multicolumn{2}{|c|}{$2010 / 2011$} \\
\hline & & WUE & WP & WUE & WP & WUE & WP \\
\hline \multirow{3}{*}{$\mathrm{I}_{1}$} & $\mathrm{~V}_{1}$ & 13.62 & 8.21 & 12.45 & 7.79 & 12.69 & 7.65 \\
\hline & $\mathrm{V}_{2}$ & 14.84 & 9.17 & 14.91 & 9.11 & 15.05 & 9.29 \\
\hline & $\mathrm{V}_{3}$ & 16.88 & 10.73 & 25.20 & 8.77 & 16.12 & 9.45 \\
\hline \multicolumn{2}{|c|}{ Mean } & 15.11 & 9.65 & 17.52 & 8.56 & 14.62 & 8.80 \\
\hline \multirow{3}{*}{$\mathrm{I}_{2}$} & $\mathrm{~V}_{1}$ & 11.78 & 7.10 & 9.62 & 5.80 & 10.55 & 6.36 \\
\hline & $\mathrm{V}_{2}$ & 12.40 & 7.57 & 11.30 & 6.85 & 11.29 & 6.97 \\
\hline & $\mathrm{V}_{3}$ & 18.95 & 8.00 & 12.34 & 7.46 & 13.86 & 6.27 \\
\hline \multicolumn{2}{|c|}{ Mean } & 14.38 & 7.56 & 11.09 & 6.70 & 11.90 & 6.53 \\
\hline \multirow{3}{*}{$\mathrm{I}_{3}$} & $\mathrm{~V}_{1}$ & 10.12 & 6.10 & 8.42 & 5.07 & 9.92 & 5.98 \\
\hline & $\mathrm{V}_{2}$ & 12.24 & 7.50 & 9.17 & 6.10 & 8.81 & 5.33 \\
\hline & $\mathrm{V}_{3}$ & 12.55 & 7.74 & 9.55 & 6.24 & 10.54 & 6.37 \\
\hline \multicolumn{2}{|c|}{ Mean } & 11.64 & 7.11 & 9.05 & 5.80 & 9.76 & 5.89 \\
\hline \multirow{3}{*}{ I4 } & V1 & 9.82 & 5.92 & 8.3 & 5.00 & 8.40 & 5.10 \\
\hline & $\mathrm{V} 2$ & 10.24 & 6.19 & 9.08 & 5.48 & 9.83 & 5.95 \\
\hline & V3 & 9.57 & 5.82 & 9.81 & 6.10 & 10.25 & 6.18 \\
\hline \multicolumn{2}{|c|}{ Mean } & 9.88 & 5.98 & 9.06 & 5.53 & 9.49 & 5.74 \\
\hline
\end{tabular}

Storability

Data in Table (9) reveal that, in general, under the adopted irrigation treatments the values of bulb weight losses\% significantly increased as the storage period increased. Data also clear out that lower values of bulb weight losses $\%$ were obtained under $\mathrm{I}_{3}$ irrigation treatment after two and four months storage periods, whereas after six months storage one, $\mathrm{I}_{4}$ irrigation treatment exhibited lower value and such trend was true in 3 successive seasons. However, Shock et al., (1998) found a substantial increase of decomposition in onion during storage with increasing irrigation. In this sense, Satyendra $e t$ al., (2007) stated that irrigation at $0.80 \mathrm{Ep}$ resulted into minimum physiological loss in weight $\%$ for onion during 60 days of storage, while extended storage period, decreasing irrigation $(0.60 \mathrm{Ep})$ had adverse effect on storability of the onion bulbs. These variations may be attributed to the difference in assessed irrigation treatments and/or onion varieties besides prevailing weather conditions during the storage periods. Rabbani et al. (1986) reported that storage losses in onion could be as high as 66\% and many

Fayoum J. Agric. Res. \& Dev., Vol. 26, No.2, July, 2012 
factors, such as cultivars, bulb maturity, moisture content of the bulb, temperature, relative humidity, etc. are associated with spoilage of onion during storage.

Regardless irrigation treatments, the onion varieties exerted a significant effect to alter onion bulb weight losses\% due to the adopted storage periods. Data in Table (9) illustrate that the lower values of weight bulb losses\% were exhibited by Giza 6 mohassan variety, comparable with Giza 20 and Giza red onion ones, respectively, in 3 consecutive growing seasons.

Table 9. Weight losses percentage after 2,4 and 6 months as affected by irrigation treatments on same onion varieties in 2008/2009, 2009/2010 and 2010 / 2011 seasons.

\begin{tabular}{|c|c|c|c|c|c|c|c|c|c|c|}
\hline \multirow{3}{*}{$\begin{array}{c}\text { Irrigation } \\
\text { Counts "A" }\end{array}$} & \multirow{3}{*}{$\begin{array}{c}\text { Varieties } \\
\text { "B" }\end{array}$} & \multicolumn{9}{|c|}{ Weight losses (\%) } \\
\hline & & \multicolumn{3}{|c|}{2 months } & \multicolumn{3}{|c|}{4 months } & \multicolumn{3}{|c|}{6 months } \\
\hline & & $1^{\mathrm{st}}$ & $2^{\text {nd }}$ & $3^{\text {rd }}$ & $1 \stackrel{\mathrm{st}}{\mathrm{s}}$ & $2^{\text {nd }}$ & $3^{\mathrm{rd}}$ & $1 \stackrel{\mathrm{st}}{\mathrm{s}}$ & $2^{2 \mathrm{nd}}$ & $3^{\text {rd }}$ \\
\hline \multirow[t]{3}{*}{$\overline{\mathrm{I}_{1}}$} & $\overline{\mathrm{V}_{1}}$ & 14.85 & $\overline{12.11}$ & $\mid 12.54$ & 18.06 & 16.07 & 17.06 & $\overline{c 56.59}$ & $\overline{66.88}$ & $\overline{56.83}$ \\
\hline & $\mathrm{V}_{2}$ & 33.39 & 30.18 & 34.62 & 37.15 & 37.07 & 34.19 & 90.58 & 80.55 & 84.91 \\
\hline & $\mathrm{V}_{3}$ & 35.61 & 23.62 & 32.64 & 34.96 & 26.90 & 32.93 & 91.83 & 90.04 & 89.81 \\
\hline \multicolumn{2}{|l|}{ Mean } & 27.95 & 21.97 & 26.60 & 30.06 & 26.68 & 28.06 & 79.67 & 79.15 & 77.18 \\
\hline \multirow[t]{3}{*}{ 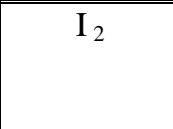 } & $\mathrm{V}_{1}$ & 15.42 & 12.71 & 12.38 & 18.89 & 17.79 & 21.77 & 50.87 & 48.99 & 49.54 \\
\hline & $\mathrm{V}_{2}$ & 35.57 & 31.88 & 30.12 & 40.87 & 36.90 & 40.68 & 88.84 & 86.84 & 89.22 \\
\hline & $\mathrm{V}_{3}$ & 37.07 & 29.26 & 31.56 & 37.55 & 38.51 & 42.44 & 87.18 & 88.55 & 88.28 \\
\hline \multicolumn{2}{|l|}{ Mean } & 29.35 & 24.62 & 24.69 & 32.44 & 31.06 & 34.96 & 57.63 & 74.79 & 75.68 \\
\hline \multirow[t]{3}{*}{ 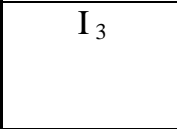 } & $\mathrm{V}_{1}$ & 21.30 & 19.44 & 21.24 & 21.60 & 23.57 & 20.22 & 50.33 & 57.45 & 56.32 \\
\hline & $\overline{V_{2}}$ & 26.74 & 21.73 & 23.38 & 30.64 & 20.73 & 28.32 & 81.31 & 74.60 & 72.38 \\
\hline & $\mathrm{V}_{3}$ & 22.87 & 24.62 & 25.76 & 25.72 & 23.70 & 30.61 & 82.50 & 82.61 & 80.67 \\
\hline \multicolumn{2}{|l|}{ Mean } & 23.64 & 21.93 & 23.46 & 25.99 & 22.67 & 26.38 & 71.38 & 71.55 & 69.79 \\
\hline \multirow[t]{3}{*}{$\overline{\mathrm{I}_{4}}$} & $\mathrm{~V}_{1}$ & 28.64 & 34.18 & 31.96 & 23.86 & 39.18 & 34.06 & 58.75 & 58.98 & 52.36 \\
\hline & $\mathrm{V}_{2}$ & 25.86 & 28.32 & 24.53 & 28.33 & 36.67 & 37.58 & 56.43 & 56.32 & 53.01 \\
\hline & $\mathrm{V}_{3}$ & 24.94 & 32.09 & 29.73 & 31.58 & 47.72 & 36.47 & 57.43 & 70.13 & 59.49 \\
\hline \multicolumn{2}{|l|}{ Mean } & 26.48 & 29.53 & 28.74 & 27.93 & 441.19 & 36.04 & 57.54 & 61.84 & 54.95 \\
\hline Mean over & $\overline{\mathrm{V}_{1}}$ & 20.05 & 19.61 & 19.53 & 20.61 & 24.15 & 23.28 & $\overline{54.14}$ & 58.07 & 53.76 \\
\hline \multirow[t]{2}{*}{ Cultivars } & $\mathrm{V}_{2}$ & 30.39 & 26.52 & 28.16 & 34.25 & 32.84 & 35.19 & 79.29 & 74.58 & 74.88 \\
\hline & $\mathrm{V}_{3}$ & 30.12 & 27.39 & 29.92 & 32.45 & 34.21 & 35.61 & 79.74 & 82.85 & 79.56 \\
\hline \multicolumn{2}{|l|}{ A } & 3.369 & 2.519 & \begin{tabular}{|l|l|}
3.328 \\
\end{tabular} & NS & 5.272 & 3.936 & 2.123 & 4.757 & 3.946 \\
\hline \multicolumn{2}{|c|}{ L.S.D at $5 \%$ for B } & 5.603 & 2.635 & 2.800 & 2.234 & 3.136 & 3.173 & 4.577 & 4.015 & 5.176 \\
\hline \multicolumn{2}{|c|}{$\mathrm{A} * \mathrm{~B}$} & 5.650 & 5.803 & 7.703 & 8.302 & 4.058 & 6.974 & 10.441 & 7.325 & 6.541 \\
\hline
\end{tabular}

The interaction effects of the adopted treatments on onion bulb storability were almost significant under the different storage periods in 3 successive seasons. Generally, the lower values of weight bulb losses\% were recorded due to

One of the main advantages with irrigation is the ability to meet crop water requirements. This is particularly important as the crop matures, as over watering on onion crop near harvest can damage the bulbs and reduce shelf life. Although irrigation increased yield it also increased the incidence of disease, and rots in storage, when the bulbs were stored for up to four months.

Fayoum J. Agric. Res. \& Dev., Vol. 26, No.2, July, 2012 
However, the predator variety was more susceptible to disease, and this susceptibility greatly increased with frequency of irrigation.

\section{REFERENCES}

Abd El-Gawwad, I.F.M (2008). Comparative evaluation of three onion cultivars under the effect of some agricultural and post-harvest treatments. M.Sc.Thesis, Hort. Dept. Fac. of Agric., Minia, Univ., Egypt.

Abu-Awwad, A.M. (1999). Irrigation water management for efficient water use in Mulched J. Onion. Agron. And Crop Sci., 183 (1):1-7.

El-Akram, M.F.I. (2012). Effect of different forms of N-fertilizer and water regime on onion production and some crop- water relations.J.Soil Sci. and Agric. Eng. Mansoura Univ., 3 (4): 443-456.

FAOSTAT (2010). On line statistical data base of the Food and Agricultural Organization of the United Nations. http:// apps.fao. org/.

Israelsen, O.W and V.E. Hansen (1962). Irrigation principles and practices. The $3^{\text {rd }}$ ed. John, Wiley and Sons Inc., New York.

Kadayifci, Abdullah, Gökhan İsmail Tuylu, Yusuf Ucar and Belgin Cakmak (2005). Crop water use of onion (Allium cepa L.) in Turkey. Agricultural Water Management, 72, (1) 1: 59-68.

Klute, A. (1986). Methods of Soil Analysis. Part 1. 2nd ed. ASA and SSSA. Madison, Wisconsin, USA.

Nandi, R.K., M. Deb, T.K. Maity and G. Sounda (2002). Response of onion to different levels of irrigation and fertilizer. Crop Research Hisar. 23(2): 317-320.

Page, A.L., R.H. Miller and D.R. Keeny (1982). Methods of soil analysis. Part@II. Chemical and Microbiological properties 2nd ed. Amer. Soc. Agron. Inc. Soil Sci. Sco. Amer. Inc. Madison, Wisconsin, USA.

Pelter, G.Q.; M. Robert; G.L. Brian and A.R. Cristoti (2004). Effects of water stress at specific growth stages on onion bulb yield and quality. Agricultural Water Management, 68, (2):107:115.

Piper, C.S. (1950). Soil and plant analysis. Univ. of Adelaid. Australia.

Rabbani, M.G.; A. Hussain, M.A. Siddique and A.H.M. Faruque (1986). Yield and storability of seven onion (Allium cepa L.) cultivars. Bangladesh J. Agric. 11(4): 1-7.

Ryan, J., S. Garabet, K. Harmsen, and A. Rashid (1996). A soil and plant Analysis Manual Adapted for the west Asia and North Africa Region. ICARDA, Aleppo, Syria. 140pp.

Satyendra K.; M. Imtiyaz; A. Kumar and R. Singh (2007). Response of onion (Allium cepa L.) to different levels of irrigation water. Agricultural Water Management, 89, (1-2) :161-166.

Shock, C.C.; E.B.G. Feibert and L.D. Saunders (1998). Onion yield and quality affected by soil water potential as irrigation threshold. Hort. Sci., 33(7): 1188-1191.

Senedecor, G.W. and W.G. Cochran (1980): Statistical Methods, $7^{\text {th }}$ Ed. Iowa, U.S.A.

Soujala, T.; T. Salo and R. Pessala (1998). Effects of fertilization and irrigation practices on yield, maturity and storability of onions. Agric. and Food Sci. in Finland. 7(4): 477- 489.

Vites, F.G. (1965). Increasing water use efficiency by soil management in plant environment and efficient water use. J. American Soc. Agronomy., 26: 537-546

Fayoum J. Agric. Res. \& Dev., Vol. 26, No.2, July, 2012 
Waller, R. A. and C. B. Duncan (1969). Abays rule for symmetric multiple comparison problem Amer. State Assoc. Jour. December: 14851503 .

\section{تقييم تأثير عدد الريات علي النمو و المحصول و القدرة التخزينية} وإنتاجية وحدة المياه لبعض أصناف البصل البصل

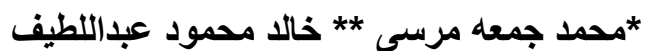

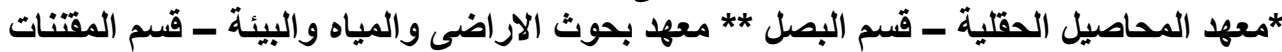
المائية والرى الحقلى - مركز البحوث الزئه الزراعية.

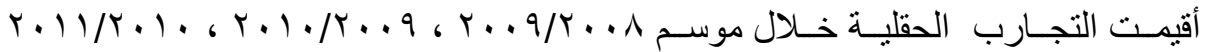

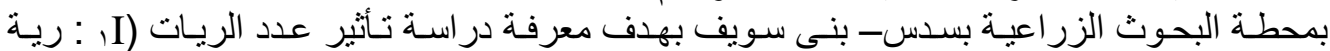

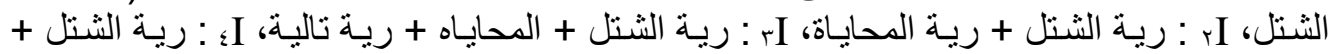

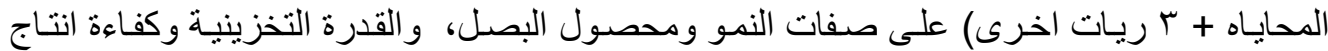

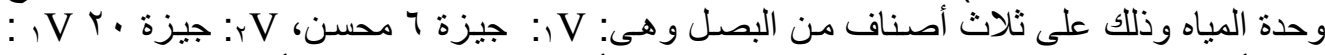
جيزة أحمر و استخدم فى ذللك تصميم القطع المنشقة فى أربعة مكرر المات وكانت الهم أهم النتائج المتحصل

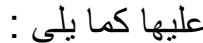

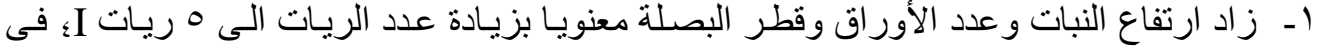

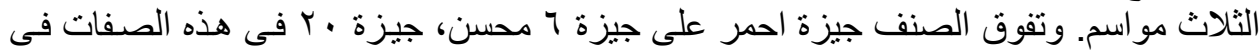

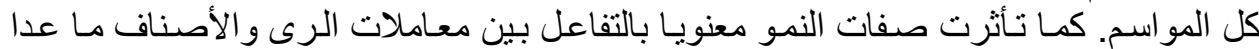

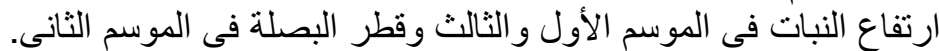

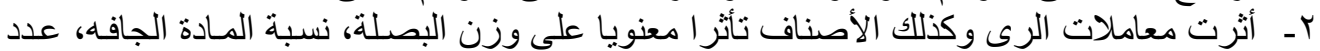

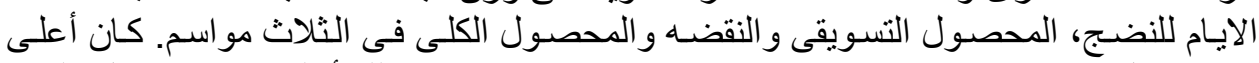

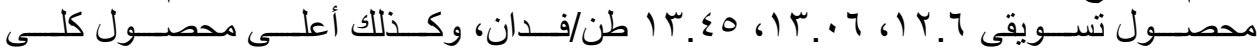

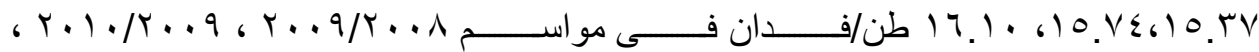

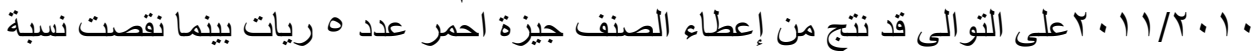

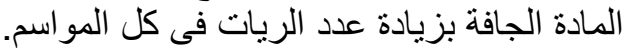

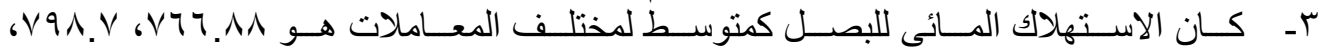

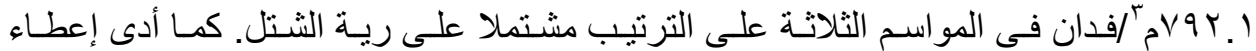

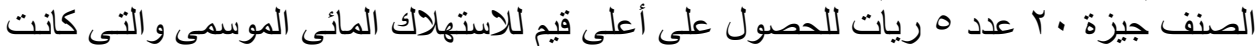

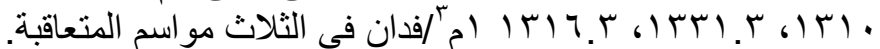

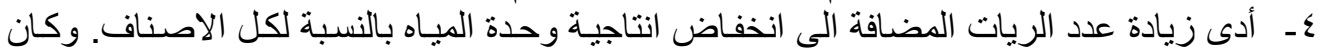

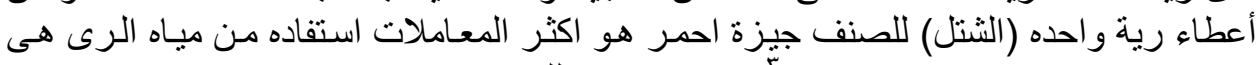

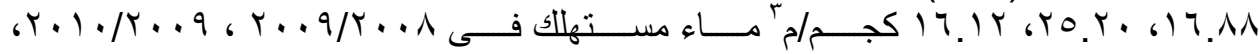

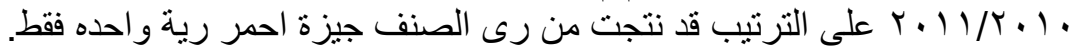

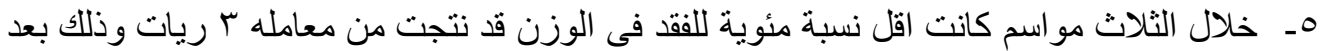

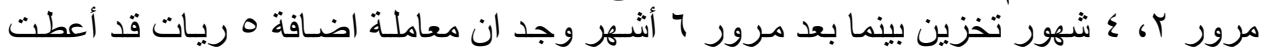

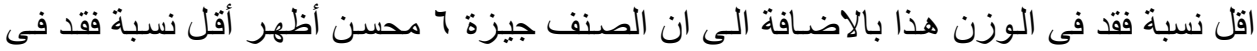
الوزن مقارنة بجيزة · ب وجيزة احمر. 